\title{
Myxobolus sp. (Myxozoa) in the circulating blood of Colossoma macropomum (Osteichthyes, Characidae)
}

\author{
Myxobolus sp. (Myxozoa) no sangue circulante de Colossoma macropomum (Osteichthyes, Characidae) \\ Patricia Oliveira Maciel ${ }^{1,2 *}$; Elizabeth Gusmão Affonso²; Cheila de Lima Boijink³; \\ Marcos Tavares-Dias ; ; Luis Antonio Kioshi Aoki Inoue ${ }^{3}$
}

${ }^{1}$ Embrapa Pesca e Aquicultura, Empresa Brasileira de Pesquisa Agropecuária - EMBRAPA

${ }^{2}$ Departamento de Aquicultura, Instituto Nacional de Pesquisa na Amazônia - INPA

${ }^{3}$ Embrapa Amazônia Ocidental, Empresa Brasileira de Pesquisa Agropecuária - EMBRAPA

${ }^{4}$ Embrapa Amapá, Empresa Brasileira de Pesquisa Agropecuária - EMBRAPA

Received July 28, 2010

Accepted December 3, 2010

\begin{abstract}
Myxosporea parasitize many organs in fresh and saltwater fish. Species of the genus Myxobolus parasitizing the gills and other organs of the tambaqui Colossoma macropomum have been described. In the present study, blood smears were made from juvenile tambaqui and were stained with May Grunwald-Giemsa-Wright in order to identify myxozoan parasites. Out of a total of 36 fish examined, one specimen (2.7\%) that was reared in a cage presented spores that were identified as M. colossomatis, whereas fish kept in $250 \mathrm{~L}$ tanks showed prevalence of $5.5 \%$. This is the first report of M. colossomatis in the blood of farmed tambaqui in the Amazon region. These results indicate that myxozoan parasites should also be investigated in fish blood smears. Some myxosporean species may cause diseases in fish, and these species need to be identified so that adequate preventive sanitary control can be instituted.
\end{abstract}

Keywords: Fish farming, freshwater fish, parasites, Myxobolus.

\section{Resumo}

Mixosporídeos parasitam diversos órgãos de peixes de água doce e salgada, tendo sido descrita espécie do gênero Myxobolus parasitando brânquias e outros órgãos de tambaqui Colossoma macropomum. No presente trabalho, extensóes sanguíneas de juvenis de tambaquis foram confeccionadas e coradas com May Grunwald-Giemsa-Wright para identificação de parasitos myxozoários. Do total de 36 peixes examinados, um espécime (2,7\%) cultivado em tanquerede apresentou esporos identificados como M. colossomatis, enquanto os peixes mantidos em tanques com $250 \mathrm{~L}$ apresentaram prevalência de $5,5 \%$. Esse é o primeiro registro de $M$. colossomatis no sangue de tambaqui cultivado na Amazônia. Esses resultados indicam que parasitos Myxozoa devem ser também investigados em extensóes sanguíneas. Algumas espécies de mixosporídeos podem causar doença em peixes, sendo necessária a identificação da espécie para um adequado manejo sanitário preventivo.

Palavras-chave: Piscicultura, peixe de água doce, parasitas, Myxobolus.

\section{Introduction}

The tambaqui (Colossoma macropomum) is one of the mostconsumed fish in the central Amazon region. For this reason, it is sensitive to diminished natural stocks in the areas surrounding large cities like Manaus, and this favors fish farming on a variety of scales, as a commercially profitable alternative (ROUBACH et al., 2003). Currently, as well as being the third most farmed species in Brazil, it is the native species most reared in the Northern

${ }^{*}$ Corresponding author: Patricia Oliveira Maciel

Empresa Brasileira de Pesquisa Agropecuária, Embrapa Pesca e Aquicultura, Av. JK ACSO 1, 103 S Conj 1, Lote 17, Piso 1, Centro,

CEP 77015-012, Palmas - TO, Brazil;

e-mail: patricia.maciel@embrapa.br region of Brazil. Modern farming techniques have been developed and adopted by rural producers, with significant profits in the regional aquiculture sector (OSTRENSKY et al., 2008). However, problems relating to parasitic diseases among farmed fish still occur frequently, especially diseases that are triggered by improper management. This has stimulated a search for information on the parasites that may affect tambaqui, such as myxosporean parasites (TAVARES-DIAS et al., 2006; THATCHER, 2006). Among these, the genus Myxobolus has the greatest diversity, with 450 species described (BÉKÉSI; SZÉKELY; MOLNÁR, 2002; MOLNÁR, 2002). Some of the species of Myxobolus are known to be pathogenic, such as $M$. cerebralis, which causes specific diseases 
in the fry of regional and exotic species, such as the whirling disease of salmonids. Myxobolosis of the tambaqui, caused by Myxobolus colossomatis, was first found in Brazil by Molnár and Békési (BÉKÉSI; SZÉKELY; MOLNÁR, 2002). With the aim of contributing towards the knowledge of parasitic diseases among tambaqui in captivity, the present study investigated blood smears to diagnose and identify myxosporean parasites.

\section{Material and Methods}

Samples were taken from 36 fish $(216 \pm 7 \mathrm{~g}$ and $22 \pm 0.4 \mathrm{~cm})$ that were reared in cages of volume $1 \mathrm{~m}^{3}$ laid out in a catch-and-pay lagoon, and from 90 fish $(32.0 \pm 8.1 \mathrm{~g}$ and $10.1 \pm 0.9 \mathrm{~cm})$ that were kept in $250 \mathrm{~L}$ PVC tanks with constant renewal of the water, under laboratory conditions. The samples were collected in the first and second halves of the year 2008, respectively, in the municipality of Manaus, Amazonas. In both of the rearing schemes, the first were fed every day, at two times of the day, with commercial feed containing $32 \%$ raw protein. The parameters relating to water quality in the lagoon were: temperature $29.1 \pm 0.8^{\circ} \mathrm{C}$, dissolved oxygen $8.0 \pm 0.7 \mathrm{mg} . \mathrm{L}^{-1}$ and $\mathrm{pH} 5.2 \pm 1.5$; and in the cages: temperature $26.0 \pm 0.7^{\circ} \mathrm{C}$, dissolved oxygen $7.5 \pm 0.8 \mathrm{mg} . \mathrm{L}^{-1}$; conductivity $22.2 \pm 2.3 \mu \mathrm{S} . \mathrm{cm}^{-3} ; \mathrm{pH} 7.0 \pm 0.1 ; \mathrm{CO}_{2} 6.7 \pm 2.8 \mathrm{mg} . \mathrm{L}^{-1}$; total alkalinity $1.65 \mathrm{mg} . \mathrm{L}^{-1}$ and total hardness $1.33 \pm 0.30 \mathrm{mg} . \mathrm{L}^{-1}$.

Blood samples were obtained from the fish by means of puncturing the caudal vein, using syringes containing 10\% EDTA. Blood smears were produced and subjected to panchromatic staining using the May-Grünwald-Giemsa-Wright method (TAVARES-DIAS; MORAES, 2003), in order to identify myxozoan spores in accordance with the recommendations of Molnár and Békési (1993) and Thatcher (2006), while the prevalence was calculated in accordance with Bush et al. (1997). The spores were measured using specific software for the Olympus BX51 microscope, in accordance with the recommendations of Békési, Székely and Molnár (2002).

\section{Results, Discussion and Conclusion}

The blood smears from the tambaqui in the cage system and in the laboratory (PVC tanks) revealed that spores with two polar capsules were present. These were identified as parasites of the genus Myxobolus (Myxobolidae: Myxozoa). Figure 1 shows a blood smear from a caged tambaqui, in which myxobolid spores that are on the point of bursting inside a blood cell can be seen. The spores that were found $(\mathrm{n}=4)$ had a mean length of $9.55 \mu \mathrm{m}$ (range: $9.08-10.28$ ), a mean width of $4.98 \mu \mathrm{m}$ (range: $4.64-5.11$ ), a polar capsule length of $5.52 \mu \mathrm{m}$ (range: $4.90-6.30$ ) and polar capsule width of $1.57 \mu \mathrm{m}$ (range: $1.31-1.70)$. The prevalences of Myxobolus sp. in the blood smears from the tambaqui in the cage system and laboratory were $2.7 \%$ and $5.5 \%$, respectively.

The species Myxobolus colossomatis has been described as a parasite of the gills and other organs in tambaqui, pacu (Piaractus mesopotamicus) and their hybrid, the tambacu (MOLNÁR; BÉKÉSI, 1993; MARTINS et al., 1999; BÉKÉSI; SZÉKELY; MOLNÁR, 2002). Myxosporeans parasitize various organs of fresh and saltwater fish and can be found in intercellular spaces

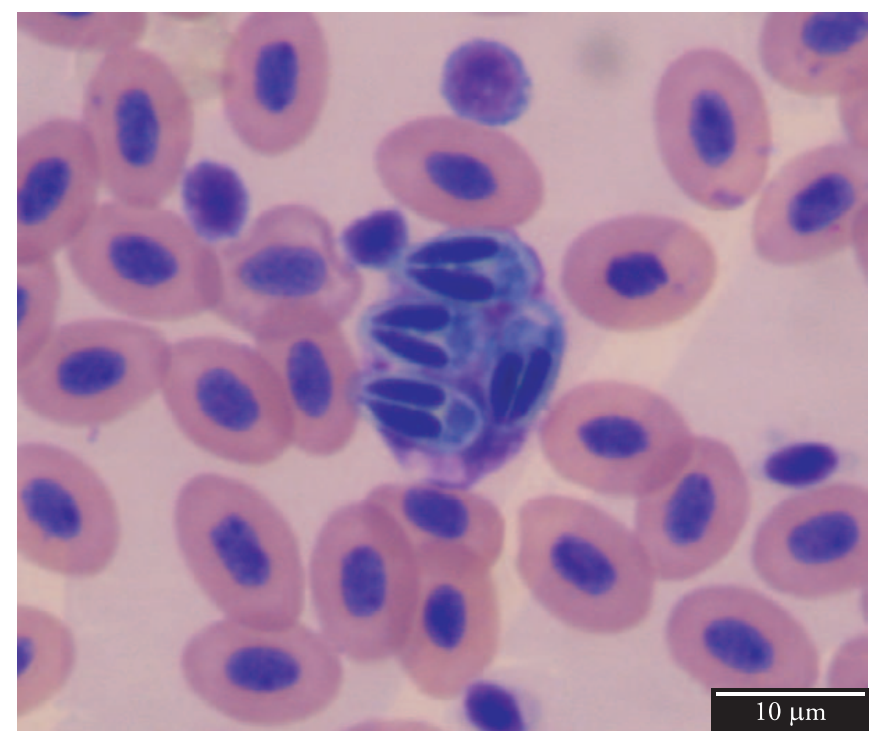

Figure 1. Blood smear from tambaqui (Colossoma macropomum) stained with May-Grünwald-Giemsa-Wright, showing spores of Myxobolus sp. inside a blood cell that is on the point of bursting. Bar $=10 \mu \mathrm{m}$.

and/or inside cells, in blood vessels, the swim bladder, gills, spleen, liver, kidney and musculature (NOGA, 2000; AZEVEDO; CORRAL; MATOS, 2002; LUQUE, 2004; MATOS et al., 2004; TAVARES-DIAS et al., 2006; THATCHER, 2006). The pathogenesis of infections due to Myxobolus involves absorption of the cells of the parasitized organ, thereby reducing its functional capacity (THATCHER, 1981), as well as an advanced stage of lysis and even tissue necrosis, which suggests that the host could be killed by the parasitism (MATOS et al., 2004). In pacu, there have been reports of hemorrhage in the primary gill lamellae and pallor in parasitized liver, kidney and spleen, along with histological alterations in these tissues (MARTINS et al., 1999). However, it has been emphasized that in most cases, the infection is asymptomatic (TAVARES-DIAS et al., 2006; THATCHER, 2006).

The diagnosis of myxosporidiosis is made mainly through identifying the spore of the parasite in the tissue of the target organ, in imprints of organs stained with Giemsa, in histopathological examinations or in freshly observed scrapings from mucosa and gills (MARTINS et al., 1999; NOGA, 2000; EIRAS; TAKEMOTO; PAVANELLI, 2006; TAVARES-DIAS et al., 2006). In the literature, it was not possible to find any relationship between the prevalence of Myxobolus sp. and the form or condition of rearing tambaqui. Using histopathological techniques, Martins et al. (1999) found a low prevalence $(5.6 \%)$ of myxosporeans in tambaqui farmed in the State of Sáo Paulo, in contrast with the high prevalence (97.3\%) in pacu. Low prevalence of $M$. colossomatis in tambaqui gills (2.9\%) was also reported by Matsunae (2000). On the other hand, Tavares-Dias et al. (2006) found higher prevalence of this myxosporean in the gills and skin of cultivated tambaqui from Experimental Estation of Fish Farm (46.6\%). However, in addition to the target organs cited, blood stages of myxosporeans can also be detected in fresh blood (EIRAS; TAKEMOTO; PAVANELLI, 2006). In the present study, the possibility of 
blood contamination through the presence of Myxobolus sp., in the form of plasmodium or free spores in the mucosa, epithelium or connective tissues affected during puncture of the caudal vein. However, some studies (MARTINS et al., 1999; MATSUNAE, 2000; TAVARES-DIAS et al., 2006) have described prevalences of $M$. colossomatis in apparently healthy tambaqui, using diagnostic methods differing from those used in the present study (which used blood smears). These other studies suggest that there is a possibility that the spores found in the present study were developmental stages of Myxobolus sp. that may form part of its life cycle (plasmodium or free spores) in the peripheral blood of the fish, as reported by Molnár (2002) in relation to another myxosporean species. In addition, blood tissue is also a form of dispersion of myxosporean parasites to other organs in fish. However, it has been suggested that the technique for detecting spores in fresh blood is questionable, since low-intensity parasitosis or apparently asymptomatic infections may go unnoticed (EIRAS; TAKEMOTO; PAVANELLI, 2006). Thus, diagnoses of myxosporeans in fish blood have not been documented with any frequency in the literature.

The present study is the first report on Myxobolus sp. in the peripheral blood of tambaqui, and it indicates that the blood is a tissue that should also be investigated for the presence of these parasites. Myxosporeans are identified at species level with the aid of a transmission electron microscope or molecular biology (AZEVEDO; CORRAL; MATOS, 2002; ADRIANO et al., 2009). The spore measurements found in the blood smears recorded in the present study were smaller than those described for M. colossomatis by Molnár and Békési (1993). Therefore, even with frequent occurrences of $M$. colossomatis in farmed and wild tambaqui, involvement of this species of myxosporean cannot be confirmed in the present study: some of the tools cited earlier would be required for this. Nonetheless, to add information on Myxobolus sp., and in the knowledge that some species of myxosporeans with affinity for fish compromise the health of these fish, studies that broaden the knowledge of these parasites to help in adequate preventive sanitary management are of great importance, thereby avoiding economic losses in commercial fish farming in the future.

\section{Acknowledgements}

To Dr. Eliana Feldberg and her MSc students Carlos Henrique Schneider and Maria Leandra Terêncio, at the Animal Genetics Laboratory of the National Institute of Amazonian Research, for assistance in measuring the spores.

\section{References}

ADRIANO, E. A. et al. Myxobolus cordeiroi n. sp., a parasite of Zungaro jahu (Siluriformes: Pimelodiade) from Brazilian Pantanal: Morphology, phylogeny and histopathology. Veterinary Parasitology, v. 162, n. 3-4, p. 221-229, 2009.

AZEVEDO, C.; CORRAL, L.; MATOS, E. Myxobolus desaequalis n. sp. (Myxozoa, Myxosporea), parasite of the Amazonian freshwater fish, Apteronotus albifrons (Teleostei, Apteronotidae). Journal Eukaryotic Microbiology, v. 49, n. 6, p. 485-488, 2002.
BÉKÉSI, L.; SZÉKELY, C.; MOLNÁR, K. Atuais conhecimentos sobre Myxosporea (Myxozoa), parasitas de peixes. Um estágio alternativo dos parasitas no Brasil. Brazilian Journal Veterinary Research Animal Science, v. 39, n. 5, p. 271-276, 2002.

BUSH, A. O. et al. Parasitology meets ecology on its own terms: Margolis et al. Revisited. Journal of Parasitology, v. 83, n. 4, p. 575-583, 1997.

EIRAS, J. C.; TAKEMOTO, R. M.; PAVANELlI, G. C. Métodos de estudo e técnicas laboratoriais em parasitologia de peixes. 2. ed. Universidade Estadual de Maringá, 2006. 199 p.

LUQUE, J. L. Biologia, epidemiologia e controle de parasitos de peixes. Revista Brasileira de Parasitologia Veterinária, v. 13, Supl. 1, p. 161-165, 2004.

MARTINS, M. L. et al. Comparative evaluation of the susceptibility of cultivated fishes to the natural infection with myxosporean parasites and tissue changes in the host. Revista Brasileira de Biologia, v. 59, n. 2, p. 263-269, 1999.

MATOS, E. et al. Microorganismos Parasitos de Animais Aquáticos da Amazônia. In: RANZANI-PAIVA, M. J. T.; TAKEMOTO, R. M.; LIZAMA, M. A. Sanidade de Organismos Aquáticos. São Paulo, 2004. p. 159-178.

MATSUNAE, J. Monitoramento da parasitofauna de alevinos de tambaqui, Colossoma macropomum (Cuvier, 1818), em barragem de igarapé de terra firme, Iranduba - AM. 2000. 71 f. Dissertação (Mestrado)-Instituto Nacional de Pesquisas da Amazônia, Universidade Federal do Amazonas.

MOLNÁR, K. Site preference of fish myxosporeans in the gill. Diseases of Aquatic Organisms, v. 48, n. 3, p. 197-207, 2002.

MOLNÁR, K.; BÉKÉSI, L. Description of a new Myxobolus species, M. colossomatis $\mathrm{n}$. $\mathrm{sp}$. from the teleost Colossoma macropomum of the Amazon River basin. Journal of Applied Ichthyology, v. 9, n. 1, p. 57-63, 1993.

NOGA, E. J. Fish disease: diagnosis and treatment. Iowa, U.S.A.: Blackwell Publishing, 2000. 367 p.

OSTRENSKY, A.; BORGHETTI, J. R.; SOTO, D. Aqüicultura no Brasil. O desafio é crescer. Brasília, DF, 2008. 276 p.

ROUBACH, R. et al. Aquaculture in Brazil. World Aquaculture, n. 34, p. 28-35. 2003.

TAVARES-DIAS, M.; MORAES, F. R. Características hematológicas da Tilapia rendalli Boulenger, 1896 (Osteichthyes: Cichlidae) capturada em "Pesque-pague" de Franca, São Paulo, Brasil. Bioscience Journal, v. 19, n. 1, p. 107-114, 2003.

TAVARES-DIAS, M. et al. Ocorrência de ectoparasitos em Colossoma macropomum Cuvier, 1818 (Characidae) cutivados em estaçáo de piscicultura na Amazônia Central. CIVA, 2006. p. 726-731. Disponível em: <http://www.revistaaquatic.com/civa2006/coms/ completo.asp? $\operatorname{cod}=150>$.

THATCHER, V. E. Patologia de peixes da Amazônia Brasileira, 1. Aspectos gerais. Acta Amazônica, v. 11, n. 1, p. 125-140, 1981.

THATCHER, V. E. Amazon fish parasites. Sofia-Moscow: Pensoft Publishers, 2006. 508 p. 